Discourse in Filipino Philosophy

\title{
Postmodernism from the Perspectives of Filipino Philosophers: Abulad, Co, Demeterio, and Pavo
}

\author{
Mary Irene Clare O. Deleña \\ and Raymond John D. Vergara
}

\begin{abstract}
Postmodernism may have originated from the west, but the Philippines as an English-speaking neo-colonial state that is thrust into context of globalization could not remain for long unaffected by the impact of this cultural and philosophical movement or trend. This paper analyzed postmodernism as seen by four Filipino philosophy scholars who are known in as far as the field of Filipino philosophy is concerned: Romualdo Abulad, Alfredo Co, Feorillo Demeterio III, and Raymundo Pavo. This paper made thematic, comparative and contrastive readings of the relevant essays of these four Filipino philosophy scholars in accordance to their: 1) definitions of postmodernism, 2) aspects of postmodernism analyzed, 3) discursive positioning, 4) underpinning concerns, and 5) general appraisals of postmodernism. The overall aim of this paper is to provide an initial assessment on how postmodernism has impacted the Philippines and how Filipino philosophy is coming to terms with this predominantly western phenomenon.
\end{abstract}

Keywords: postmodernism, Philippine context, Filipino philosophy, thematic reading

\section{Introduction}

$\mathrm{P}$ ostmodernism may have originated from the west, but the Philippines as an English-speaking neo-colonial state that was thrust into the context of globalization could not remain for long unaffected by the impact of this cultural and philosophical movement or trend. This paper analyzed postmodernism as seen by four Filipino philosophy scholars: Romualdo Abulad, Alfredo Co, Feorillo Demeterio III, and Raymundo Pavo. There are other Filipino scholars who touched on postmodernism in some of

(C) 2018 Mary Irene Clare O. Deleña and Raymond John D. Vergara https://www.kritike.org/journal/issue 22/delena\&vergara june2018.pdf ISSN 1908-7330 
their publications; but they either touched only very specific postmodern theories, like what Raniel Reyes, ${ }^{1}$ Roland Theuas Pada, ${ }^{2}$ Darlene Demandante, ${ }^{3}$ Tracy Ann Llanera, ${ }^{4}$ Daryl Mendoza, ${ }^{5}$ and Rhoderick John Abellanosa $^{6}$ had done; or talked about postmodernism from a nonphilosophical vantage point, like what Erhwin Clarin and Jennie Jocson ${ }^{7}$ Antonio Contreras, ${ }^{8}$ and Jerry Yapo ${ }^{9}$ had done. Abulad, Co, Demeterio, and Pavo, on the other hand, are Filipino philosophy scholars who talked about postmodernism in general and at the same time grappled with this cultural and philosophical phenomenon within the parameters of philosophy.

\section{Methodology}

This paper made thematic readings of the pre-identified essays of these four Filipino philosophy scholars, followed by a comparative and contrastive analyses. To make such comparative and contrastive analyses possible, this paper identified the following themes from each of the four writers and philosophers: 1) their definitions of postmodernism, 2) the aspects of postmodernism that they analyzed, 3) their discursive positioning, 4) their underpinning concerns, and 5) their general appraisals of postmodernism. The definitions of postmodernism were extracted from the essays of the said four philosophy scholars after thoroughly reading their selected publications.

\footnotetext{
${ }^{1}$ See Raniel Reyes, "Deleuze's Bergsonism: Multiplicity, Intuition, and the Virtual," in Kritike: An Online Journal of Philosophy, 10:2 (2016), 151-172. See also Raniel Reyes, "Deleuze contra Hegel: The Rupture of the Dialectics towards Non-Conceptual Differences," in Kritike: An Online Journal of Philosophy, 8:2 (2014), 118-138.

2 See Roland Theuas Pada, "Eliciting a Sense of Normativity in Derrida through Honneth's Theory of Recognition," in Kritike: An Online Journal of Philosophy, 9:1 (2015), 14-27.

3 See Darlene Demandante, "Lacanian Perspectives on Love," in Kritike: An Online Journal of Philosophy, 8:1 (2014), 102-118.

4 See Tracy Ann Llanera, "Shattering Tradition: Rorty on Edification and Hermeneutics," in Kritike: An Online Journal of Philosophy, 5:1 (2011), 108-116.

5 See Daryl Mendoza, "Commodity, Sign, and Spectacle: Retracing Baudrillard's Hyperreality," in Kritike: An Online Journal of Philosophy, 4:2 (2010), 45-59.

6 See Rhoderick John Abellanosa, "Rorty's Philosophy of Education: Between Orthodoxy and Vulgar Relativism," in Kritike: An Online Journal of Philosophy, 4:2 (2010), 87-104.

7 See Erwhin Clarin and Jennie Vergara Jocson, "Fragmentation, Intertextuality, and Hyperreality: The Postmodern and Popular Filipino Films," in Journal of Arts and Humanities, 5:5 (2016): 37-50.

8 See Antonio Contreras, "Investigating Postmodern Politics in the Philippines Using Reflexivity Theory," in Philippine Political Science Journal, 32:55 (2011), 73-102. See also Antonio Contreras, "Polity Beyond the State: 'Postodernizing' Political Science in the Philippines," in Philippine Political Science Journal, 23:46 (2002): 49-82.

${ }^{9}$ See Jerry Yapo, "Pastiche as the Aesthetic of Postmodernism in Jessica Hagedorn's Dogeaters," in The UPLB Journal, 6:1 (2009), 27.
}

(c) 2018 Mary Irene Clare O. Deleña and Raymond John D. Vergara https://www.kritike.org/journal/issue 22/delena\&vergara june2018.pdf

ISSN 1908-7330 


\section{POSTMODERNISM}

The aspects of postmodernism that were analyzed were determined using Georges de Schijver's conceptualization of postmodernism as composed of foundational and cultural aspects, with Demeterio's addition of theoretical aspect. ${ }^{10}$ Foundational aspects are: 1 ) attitude towards science and technology, 2) attitude towards the nation-state, 3) organizational management, 4) economic mode, 5) attitude towards progress, and 6) state of industry. ${ }^{11}$ Cultural aspects are: 1) the self, 2) attitude towards pleasure and consumption, and 3) art. ${ }^{12}$ Theoretical aspect refers to discourse at the level of critique and philosophy. ${ }^{13}$ By identifying which aspects of postmodernism were analyzed by the four Filipino philosophy scholars, the readers will be able to grasp how comprehensively these four tackled the said cultural and philosophical phenomena.

Discursive positioning in this paper simply means whether the specific philosophy scholar is philosophizing from a cosmopolitan point of view or from a more defined and specific local or Philippine context. As it is already expected that these four writers and philosophers had been philosophizing from mixed perspectives, this paper determined which point of view is more predominant for each of the four philosophy scholars. Discursive positioning in this paper pertains to the geographic point of view taken by the selected writers and philosophers, and has nothing to do with their epistemic positioning.

The underpinning concerns refer to the goals and intentions of each of these four philosophy scholars in tackling postmodernism in the first place. Lastly, the general appraisal of postmodernism refers to each of the four philosophy scholars' bottom line attitude towards postmodernism, whether they see it as something positive or negative, or beneficial or harmful and destructive to society and philosophy in general.

The methodology of this paper is visually represented in the following figure:

10 Georges de Schrijver, "Postmodernity and Theology," in Philippiniana Sacra, 27 (1992), 439-440 and Feorillo Demeterio, "Our Premodernity and their Tokens of Postmodernity," in Philosophia: International Journal of Philosophy, 33 (2004), 201.

${ }^{11}$ De Schrijver, "Postmodernity and Theology," 439.

12 Ibid., 440.

${ }^{13}$ Demeterio, "Our Premodernity and their Tokens of Postmodernity," 201.

(c) 2018 Mary Irene Clare O. Deleña and Raymond John D. Vergara https://www.kritike.org/journal/issue 22/delena\&vergara june2018.pdf ISSN 1908-7330

(c) BY-NC-ND 


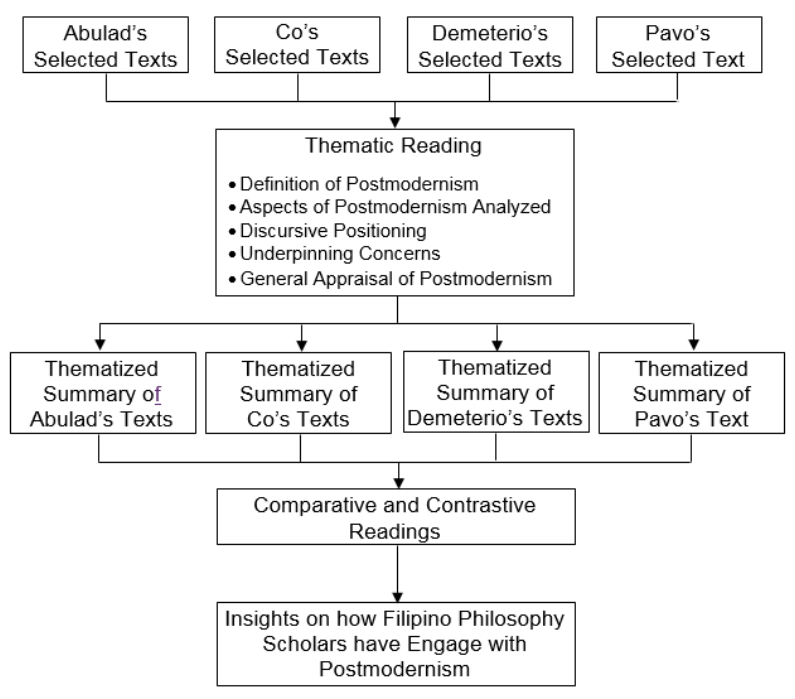

Figure 1: Visual Representation of the Paper's Methodology

To simplify the processes of comparative and contrastive readings, and make them less tedious and more efficient, tables will be used by the paper whenever applicable.

\section{Significance}

The overall aim of this paper is to provide an initial assessment on how postmodernism has impacted the Philippines by looking into how Filipino philosophy, through its representative scholars, is coming to terms with this predominantly western phenomenon. There are already countless papers that talked about postmodernism; however, there are relatively few papers that were written about it by Filipino scholars; but a thorough check using Google Scholar has established that this is first paper to analyze how Filipino philosophy scholars are making sense of and engaging with this cultural and philosophical phenomenon.

\section{Romualdo Abulad on Postmodernism}

As suggested in the preceding paragraphs, Aquinas' position on capital Abulad is a Missionary Brother of the Society of the Divine Word. He retired from De La Salle University as an associate professor of philosophy, transferred to the University of San Carlos, and upon his return to Manila started teaching as a professorial lecturer of philosophy at the University of Santo Tomas, while serving as the dean of the Christ the King Mission 
Seminary. He specializes on the philosophy of Immanuel Kant and modern and contemporary continental philosophy. In 2004, Abulad published the essays "What is Postmodernism," "Kant and Postmodernism?," "Postmodern Critique and the Ethics of Postmodernism," "The Future of Ethics: a Postmodern View," and "God and Postmodernity."

Abulad's "What is Postmodernism?" is published in the book Two Filipino Thomasian Philosophers on Postmodernism, which he co-authored with Co. Being an expert in continental philosophy, Abulad explained postmodernism as a philosophical mind frame that emanates from Friedrich Nietzsche's radical deconstructive thoughts, in contradistinction to the modern philosophical mind frame that emanates from Rene Descartes' faith on the ego and methodic doubting. It is in this essay that Abulad presented his clearest definition of what postmodernism is. He claimed that postmodernism has a negative component: "the destructive act that makes everything presumptuous, which pulverizes any entity that tends to settle the mind, so that even the mind itself, the ego or consciousness, needs to be presupposed." 14 Yet, he added that postmodernism also has a positive component: "having so cleansed our mental slate, we are then open and free enough to do the more constructive work." 15 The negative and positive aspects of postmodernism open a possibility for a "thoroughly comprehensive consciousness, integral and holistic, global and dialogical, dynamic and evolutionary." 16 The essay is an effort of an expert on modern continental philosophy to grasp postmodernism and assure his modernist and even Scholastic readers that they should not be pessimistic with the impact of postmodernism on the contemporary intellectual landscape.

Abulad's "Kant and Postmodernism" is also published in the same book. The essay has two sections, one dealing with the philosophy of Kant while the other with postmodernism. The section on Kant explored the core of Critique of Pure Reason. Abulad wrote: "The Copernican Revolution that he (Kant) has effected in philosophy is not the type of revolution that bloats the ego and augments one's feeling of self-importance. His achievement is a solid cement to what sages of all ages and climes have been trying, oftentimes vainly, to tell us. He who thinks he knows does not know, and he who knows that he does not know knows." ${ }^{17}$ The section on postmodernism does not actually talk about postmodernism in general.

\footnotetext{
${ }^{14}$ Romualdo E. Abulad, "What is Postmodernism?" in Romualdo E. Abulad and Alfredo P. Co, Two Filipino Thomasian Philosophers on Postmodernism, ed. by Romualdo E. Abulad (Manila: UST Publishing House, 2004), 33.

${ }^{15} \mathrm{Ibid}$.

${ }^{16}$ Ibid.

${ }^{17}$ Romualdo E. Abulad, "Kant and Postmodernism," in Abulad and Co, Two Filipino Thomasian Philosophers on Postmodernism, 52.

(c) 2018 Mary Irene Clare O. Deleña and Raymond John D. Vergara https://www.kritike.org/journal/issue 22/delena\&vergara june2018.pdf ISSN 1908-7330
}

(c) BY-NC-ND 
Instead, it argued how the critical spirit of Kant has influenced the deconstructive and nihilist ways of philosophizing of the postmodern period. Towards the tail end of the essay, Abulad admitted that the deconstructive and nihilist tendencies of postmodernism may not be appealing yet to many Filipinos. ${ }^{18}$ But he enticed the Filipino philosophers with the foresight that beyond deconstruction and nihilism is a vast playing field where a stronger Filipino philosophy can be built. He said: "To a Filipino, this could be good news. It means that he is now at liberty to draw up his own architectonic, based on all he knows, while deeply aware of the scope of what he does not know." 19 Like the preceding essay, "Kant and Postmodernism" is also an effort of an expert in Kantian philosophy to grasp postmodernism and again assure his modernist and even Scholastic readers that postmodern philosophy is not a fatal threat to philosophy.

Abulad's "Postmodern Critique and the Ethics of Postmodernism" is published in the same book. The intention of this essay is to present "what makes for a critique that fits the postmodern times and how it could radically alter the ethical assumptions we have grown used to." 20 To achieve such intention, the paper had to grasp first what is meant by postmodern critique and then by postmodern ethics. In talking about postmodern critique, Abulad returned to his imagery of postmodernism as composed of a negative, or critical side, and positive, or constructive side that becomes possible after razing all the unfounded structures of modernism and the classical world. ${ }^{21}$ Inspired by the ethical musings of Emmanuel Levinas, Abulad conceptualized postmodern ethics as "a formalistic ethics, an ethics without content, or else with a content which is not predetermined and so not determined from the very core of the individual who is fully conscious of his or her freedom and profound sensibility." ${ }^{22}$ Writing during the times of the Second EDSA Revolution, Abulad could only hope that the Filipino people is actually moving away from the ruins of corrupt Machiavellian politics and towards the construction of new moral and ethical governance. ${ }^{23}$ This essay appears to be an assurance to Abulad's modernist and even Scholastic readers that ethics and morality are still possible in the postmodern era.

Abulad's "The Future of Ethics: A Postmodern View" is published in the same book. This essay appears to build on the previous essay "Postmodern Critique and the Ethics of Postmodernism," in the sense that

\footnotetext{
${ }^{18}$ Ibid., 55.

${ }^{19} \mathrm{Ibid} ., 57$.

${ }^{20}$ Romualdo E. Abulad, "Postmodern Critique and the Ethics of Postmodernism," in Abulad and Co, Two Filipino Thomasian Philosophers on Postmodernism, 78.

${ }^{21}$ Ibid., 79-87.

22 Ibid., 91.

${ }^{23}$ Ibid., 90-91.
}

(c) 2018 Mary Irene Clare O. Deleña and Raymond John D. Vergara https://www.kritike.org/journal/issue 22/delena\&vergara june2018.pdf ISSN 1908-7330 
this current essay attempts to give more descriptions of what postmodern ethics is or should be. Abulad returned again to the negative project of Nietzsche with its underlying positive promise: "What, in fact, he (Nietzsche) has done for morality is cleanse it of the thick cobweb of tradition, the very reason why it has degenerated into a culture of weakness and oppression. There is no doubt that Nietzsche feels the need to destroy, but only so that he can give creation and imagination a new chance." ${ }^{24}$ Abulad's statement that postmodernism in general started around 1890 had strategically included Nietzsche in the era. ${ }^{25}$ On the other hand, Abulad maintains that postmodernism in the Catholic Church started with the Second Vatican Council. In the Philippines, furthermore, he claimed that the first EDSA Revolution signaled the emergence of postmodernism, which reminded us of the timeliness and timelessness of contemplating about ethics and morality, albeit in a different way. ${ }^{26}$ To visualize how a postmodern ethical theory may look like, Abulad took as his example Joseph Fletcher's situation ethics. Abulad argued that giving justice to Fletcher's criterion of love would require much courage and much circumspection, and very unlike the legalistic and formulaic emphases of traditional ethics. This essay, like the previous essay "Postmodern Critique and the Ethics of Postmodernism," appears to be an assurance to Abulad's modernist and even Scholastic readers that ethics and morality are still possible in the postmodern era.

Abulad's "God and Postmodernity" is published in the same book. The essay laid down the argument that if morality and ethics remained possible in the postmodern era, then religion, theology and the conceptualization of God are also possible. However, considering that there are very few postmodern thinkers who ventured into these latter topics, Abulad did not elaborate much on how these would actually be in the said era. Very broadly he argued that God anyway is somebody that would always exceed human conceptualization, thus the need for a constant review and reconstruction of our theologies. He stated: "the point where we feel we have adequately understood Christ is where we miss him; in our zeal we begin to pontificate about him and lose sight of the fact that the Christ we are forcing others to accept is nothing but our own creation." 27 This essay is an assurance to Abulad's modernist and even Scholastic readers that religion,

${ }^{24}$ Romualdo E. Abulad, "The Future of Ethics: A Postmodern View," in Abulad and Co, Two Filipino Thomasian Philosophers on Postmodernism (Manila: UST Publishing House, 2004)123.

${ }^{25} \mathrm{Ibid} ., 115$.

${ }^{26}$ Ibid.,115-116.

${ }^{27}$ Romualdo E. Abulad, "God and Postmodernism," in Two Thomasian Philosophers on Postmodernism (Manila: UST Publishing House, 2004) 205.

(c) 2018 Mary Irene Clare O. Deleña and Raymond John D. Vergara https://www.kritike.org/journal/issue 22/delena\&vergara june2018.pdf ISSN 1908-7330

(c) BY-NC-ND 
theology and the conceptualization of God are not only possible in the postmodern era but are themes that should be pursued.

Abulad claimed that postmodernism has a negative and positive component: the critique of classical and modernist thought structures on one hand, and the subsequent project of building new thought structures on less suspicious foundations on the other hand. The aspect of postmodernism that he analyzed revolved around the theoretical, as he dealt with philosophy, ethics and religion most of the time; although, when he ventured into the Philippine context he touched every now and then the cultural aspect of the said movement. His discursive positioning is both cosmopolitan and local/Philippine, although most of the time this would be cosmopolitan. This means that his geographic positioning most of the time is not that of a Filipino scholar. His underpinning concerns that this paper was able to decipher throughout his five selected essays are to: 1) insist on the possibility of ethics; 2) insist on the possibility of religion and theology; 3) make sense of postmodernism using modern continental philosophies; and 4) take advantage of the postmodern method of critique of intellectual foundations and push for the development of Filipino philosophy. His first and second, and even fourth, underpinning concerns are premised on the understanding that even if postmodernism has the tendency to raze to the grown existing intellectual structures, such tendency will be succeeded with auspicious time to build stronger and more relevant intellectual structures. His third underpinning concern is premised on the fact that Abulad is a respected expert on modern continental philosophy. Abulad's general appraisal of postmodernism is that it is something good. This means that for him, philosophy, theology, ethics, religion and Filipino philosophy should not be intimidated with postmodernism because beyond its negative aspect is its promising positive aspect.

\section{Alfredo Co on Postmodernism}

Co is a professor emeritus of philosophy at the University of Santo Tomas. He specializes on Chinese and oriental philosophy. In 2004, he published the essays "Doing Philosophy in the Philippines: Fifty Years ago and Fifty Years from Now," "Expanding Worldview in a Shrinking Planet: Reading Postmodernism in the Age of Globalization," and "And Man Created God: Understanding Postmodern Faith."

Co's "Doing Philosophy in the Philippines: Fifty Years ago and Fifty Years from Now" is a published in the book Two Filipino Thomasian Philosophers on Postmodernism, which he co-authored with Abulad. This essay presented the history of philosophy and philosophical writing in the Philippines. Emerging from a long tradition of Thomism and Scholasticism,

(c) 2018 Mary Irene Clare O. Deleña and Raymond John D. Vergara

https://www.kritike.org/journal/issue 22/delena\&vergara june2018.pdf

ISSN 1908-7330

(cc) BY-NC-ND 
the Filipino scholars who obtained their highest degrees in philosophy abroad, according to $\mathrm{Co}$, spearheaded the development of more diverse philosophy curricula in various Philippine universities, such as the University of Santo Tomas, University of the Philippines, Ateneo de Manila University, and De La Salle University. ${ }^{28}$ Co mentioned that alongside this diversification of philosophical education and writing came the establishment of a number of philosophical organizations: the Philosophical Circle of the Philippines, which he founded; the Philosophical Association of the Philippines, which was founded by Jorge Revilla; the Philosophical Association of the Visayas and Mindanao, which was founded by Quintin Terrenal; and the Philippine Academy of Philosophical Research, which was founded by Emerita Quito. ${ }^{29} \mathrm{Co}$, then, problematized what constitutes Filipino philosophy. Consequently, he proffered the answer that Filipino philosophy is the textual output of Filipinos who are actively and consciously engaged in philosophizing. ${ }^{30}$ Co banked his hopes that Filipino students and professors of philosophy will more actively engage in philosophizing especially because they are now situated in the more open, interconnected and global age of postmodernism. ${ }^{31}$ The essay only tangentially touched on postmodernism as a circumscribing period, an auspicious period, of a segment of Filipino philosophy.

Co's "Expanding a Worldview in a Shrinking Planet: Reading Postmodernism in the Age of Globalization" is published in the same book Two Filipino Thomasian Philosophers on Postmodernism. The essay started with Co's recollection on how interested some senior French government officials and professors were with his expertise on Indian and Chinese philosophies and how baffled he was at the same time why the younger French academics were swept away by the writings of Nietzsche. ${ }^{32}$ Co said that he only realized why Nietzsche had been so appealing after coming to the Philippines and delivering a lecture on this father of postmodernism. Being an expert in eastern philosophies, Co emphasized how oriental thought seeped into the west and influenced the emergence of postmodernism. ${ }^{33}$ The "expanding worldview" mentioned by Co referred to postmodernism's tolerant blending of eastern and western philosophies and its openness to other systems of thinking; while the "shrinking planet" referred to the present condition of

\footnotetext{
${ }^{28}$ Alfredo P. Co, “Doing Philosophy in the Philippines: Fifty Years Ago and Fifty Years from Now," in Abulad and Co, Two Filipino Thomasian Philosophers on Postmodernism, 1.

${ }^{29}$ Ibid.,9.

${ }^{30}$ Ibid., 13, 17.

${ }^{31}$ Ibid.,18.

32 Alfredo P. Co, "Expanding a Worldview in a Shrinking Planet: Reading Postmodernism in the Age of Globalization," in Abulad and Co, Two Thomasian Philosophers on Postmodernism, 62.

${ }^{33}$ Ibid., 63-64.
}

(c) 2018 Mary Irene Clare O. Deleña and Raymond John D. Vergara https://www.kritike.org/journal/issue 22/delena\&vergara june2018.pdf ISSN 1908-7330

(c) BY-NC-ND 
interconnectedness brought about by globalization. ${ }^{34}$ It is in this essay where Co presented his definition of postmodernism as "an offshoot of the meeting of western and eastern thought ... a way looking at the event from a 'land' perspective or a 'fish-eye' view;" while globalization is "looking at the same world from an added 'birds-eye' view." 35 But Co made the stern warning that there might be clashes and destructions that would precede the real dialogues and tolerance of postmodernity. ${ }^{36}$ The essay is an effort of an expert on oriental philosophies to grasp postmodernism using his own philosophical background.

Co's "And Man Created God: Understanding Postmodern Faith" is published in the same book. This essay tackled urbanization and technology as the driving forces of the "postmodern future." 37 Co envisioned that in such future, individuals are able to engage in the exchange of knowledge and information through the use of technology, such as the World Wide Web. Through the World Wide Web, individuals can become equals in their power to represent themselves and contribute in the exchange of knowledge. 38 Furthermore, through the World Wide Web, individuals can create and recreate their representations. ${ }^{39}$ In the postmodern age, it is no longer God who creates man. Instead, it is man who creates his/her own image. Taking this position to the extreme, Co argued that in the postmodern age, man can even create his own God, religion, and theology. ${ }^{40}$ The essay is an insistence on the possibility of religion and theology in the postmodern age.

Co stated that postmodernism emerged from the meeting of the east and the west, and that it is the ground level counterpart of globalization as being the aerial perspective on the said meeting. The aspect of postmodernism that he analyzed revolved around the theoretical, as he dealt with philosophy, religion and theology; but every now and then touched on the foundational aspect of the said movement, as he dealt with globalization and technological interconnections; and also on the cultural aspect of the same movement, as he dealt with the meeting of cultures and with the Philippine intellectual context. His discursive positioning is both cosmopolitan and local/Philippine, although most of the time this would be cosmopolitan. This means that his geographic positioning most of the time is not that of a Filipino scholar. His underpinning concerns throughout these three essays are to: 1) take advantage of postmodernism as an auspicious time

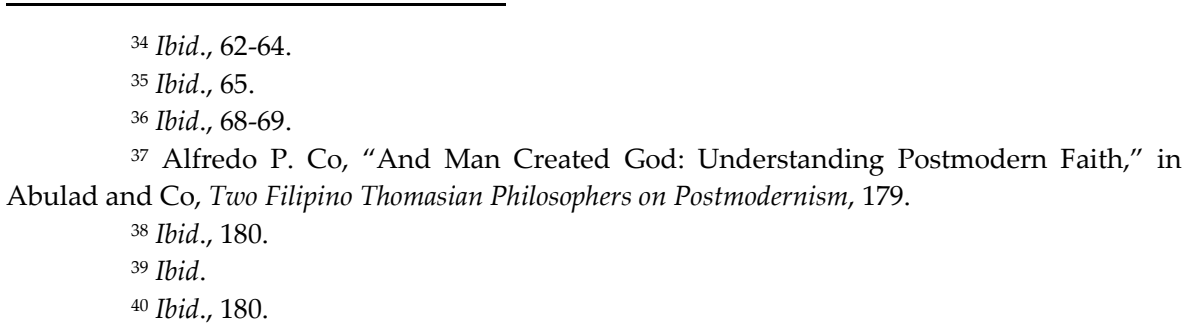

(c) 2018 Mary Irene Clare O. Deleña and Raymond John D. Vergara https://www.kritike.org/journal/issue 22/delena\&vergara june2018.pdf ISSN 1908-7330 
for the development of Filipino philosophy; 2) argue that postmodernism mooted the earlier discourses of nationalistic Filipino philosophy; 3) warn of the impending clashes and destructions that would precede the real dialogues and tolerance of postmodernity; 4) make sense of postmodernism using eastern philosophies; and 5) insist on the possibility of religion and theology. His first and fifth underpinning concerns are premised on the intellectual tolerance of postmodernism. His second underpinning concern is premised on postmodernism emphasis on globalization. His third underpinning concern is premised on his idea that the actual tolerance of postmodernism and its openness to dialogues are preceded with some violent clashes of intellectual and cultural points of view. His fourth underpinning concern is premised on the fact that Co is a respected expert on Chinese and oriental philosophy. Co's general appraisal of postmodernism is that it is both something good and evil. This means that for him, philosophy, theology, religion and Filipino philosophy should not be overwhelmed with postmodernism for the reason that after his predicted violent clashes is a time for tolerance and dialogues.

\section{Feorillo Demeterio on Postmodernism}

Demeterio is a former professor of philosophy at San Beda College (now, San Beda University) and currently a professor of Filipino and Philippine Studies at the De La Salle University. He specializes on research in Filipino philosophy and cultural studies. In between 2003 and 2015, Demeterio published the essays "Our Premodernity and their Tokens of Postmodernity: Reflections on the Philippine Condition," "Understanding the Postmodern Culture and Philosophy," "Ang Pilosopiya ni Jean-Francois Lyotard bilang Batayang Teoretikal sa Araling Pilipino," "Iris Marion Young's Theory of Structural Justice and Collective Responsibility," and "Ang Pilosopiya ni Jean Baudrillard bilang Batayang Teoretikal sa Araling Pilipino."

Demeterio's "Our Premodernity and their Tokens of Postmodernity: Reflections on the Philippine Condition" is published in Philosophia: International Journal of Philosophy. Amidst sweeping statements made by a number of Filipino academics that claim postmodernism has already transformed Philippine society, Demeterio investigated how far we can really claim such phenomenon. To be able to do so, he first conceptualized modernism and postmodernism as composed of foundational, cultural, and theoretical aspects. ${ }^{41}$ Foundational aspects are: 1) attitude towards science

${ }^{41}$ Feorillo Demeterio, “Our Premodernity and their Tokens of Postmodernity," 197-

(c) 2018 Mary Irene Clare O. Deleña and Raymond John D. Vergara

https://www.kritike.org/journal/issue 22/delena\&vergara june2018.pdf

ISSN 1908-7330

(c) $)$ BY-NC-ND 
and technology, 2) attitude towards the nation-state, 3) organizational management, 4) economic mode, 5) attitude towards progress, and 6) state of industry. ${ }^{42}$ Cultural aspects are: 1 ) the self, 2) attitude towards pleasure and consumption, and 3) art. ${ }^{43}$ Theoretical aspect refers to theoretical discussion and philosophy. ${ }^{44}$ Aspect by aspect, Demeterio determined whether Philippine society is indeed postmodern, modern or even premodern. ${ }^{45}$ In terms of foundations, the Philippine society is predominantly premodern. ${ }^{46}$ In terms of cultural expression, the Philippine society is also premodern. ${ }^{47}$ In terms of theory, the Philippine society may be both modern and postmodern. ${ }^{48}$ This essay appears to be an exploration on how Filipino philosophy can appropriate the critical philosophies of postmodernism, specifically on constructing and critiquing a model of modernity that would be more suitable for the Filipinos and free from the dark side of modernity that unfurled in the west.

Demeterio's "Understanding the Postmodern Culture and Philosophy" is published in The Philosophical Landscape. This is a straightforward introductory essay on postmodernism. Demeterio did this introduction by recalling the historical conditions that brought about the emergence of modernism and postmodernism. ${ }^{49}$ He did this also by comparing modernism and postmodernism in culture and art. ${ }^{50}$ This essay contains Demeterio's clearest definition of postmodernism as "the selfconscious cultural movement that reacted against the principles and ideals of the modernist movements in literature, art, architecture, film, philosophy, etc." 51 Towards the end of the essay, Demeterio presented the thoughts of some of the leading philosophers of postmodernism, namely: Michel Foucault, Jacques Derrida, Jean-Francois Lyotard, and Jean Baudrillard. ${ }^{52}$ This essay appears to be the author's way of explaining what postmodernism is to his neophyte Filipino readers.

Demeterio's "Ang Pilosopiya ni Jean-Francois Lyotard bilang Batayang Teoretikal sa Araling Pilipino" is published in Kritike: an Online Journal of Philosophy. This essay, written in Filipino, is Demeterio's effort in

42 Ibid., 200-203.

${ }^{43}$ Ibid., 203-205.

${ }^{44}$ Ibid., 205-206.

${ }^{45}$ Ibid., 200-206.

${ }^{46}$ Ibid., 206.

${ }^{47} \mathrm{Ibid}$.

${ }^{48} \mathrm{Ibid}$.

${ }^{49}$ Feorillo Demeterio, "Understanding the Postmodern Culture and Philosophy," in Academia, $<$ https://www.academia.edu/8244247/Understanding the_Postmodern_Culture_and_ Philosophy>.

$$
\begin{aligned}
& { }^{50} \mathrm{Ibid} \text {. } \\
& { }^{51} \mathrm{Ibid} \text {. } \\
& { }^{52} \mathrm{Ibid} .
\end{aligned}
$$

(c) 2018 Mary Irene Clare O. Deleña and Raymond John D. Vergara https://www.kritike.org/journal/issue 22/delena\&vergara june2018.pdf 


\section{POSTMODERNISM}

introducing Lyotard's postmodern thoughts to Filipino readers from the fields of both philosophy and cultural studies. ${ }^{53}$ His discussion on Lyotard's philosophy is contained in four sections: 1) critique of the status of scientific knowledge in the postmodern period, 2) implication of postmodern knowledge on tertiary education, 3) meaning of ethics and justice in the period of the micro-narratives, and 4) meaning of art in the postmodern period. ${ }^{54}$ Demeterio concluded the essay by laying down nine points on how Lyotard's philosophy can be appropriated by Filipino philosophy and Philippine studies.55 Demeterio viewed Lyotard's postmodernism as an opportunity to critique colonialism and imperialism, and at the same time multiculturalism, ethnic narratives, gender narratives, and local science and knowledge production. This essay appears to be both an introduction of Lyotard's philosophy to Filipino readers and a more concrete exploration of the possibility of appropriating Lyotard's critical thought for the enrichment and development of Filipino philosophy and Philippine studies.

Demeterio's “Iris Marion Young's Theory of Structural Justice and Collective Responsibility" is published in Scientia. It is a systematic presentation of the philosophy of the American thinker, feminist and activist, Iris Marion Young. At the time of its publication, Demeterio believed that the essay is the first systematic and comprehensive exposition of Young's contributions that are otherwise scattered in her various articles and chapters which she herself did not systematize and synthesize prior to her ailment and death. Demeterio's essay contains four substantive sections dealing with: 1) Young's theory of structural justice, 2) her theory of collective responsibility, 3) her call for a global theory of justice, and 4) her thoughts on the applicability of her philosophy to the analysis of justice in other countries. ${ }^{56}$ The essay may appear as a straightforward introduction to the philosophy of Young, but is also an insistence of Demeterio that ethics and justice can still be meaningfully pursued in the postmodern period. The essay will appear as a forthcoming chapter of Demeterio's fourth book to be published by the De La Salle University Publishing House. This forthcoming publication deals with how justice is conceptualized by the Catholic Bishops' Conference of the Philippines. Hence, the essay can also be read as Demeterio's invitation to Filipino thinkers to use postmodern theories in analyzing Philippine realities.

"Ang Pilosopiya ni Jean Baudrillard bilang Batayang Teoretikal sa Araling Pilipino" is an essay that Demeterio co-authored with Emmanuel De

\footnotetext{
${ }^{53}$ Feorillo Demeterio, "Ang Pilosopiya ni Jean-Francois Lyotard bilang Batayang Teoretikal sa Araling Pilipino," in Kritike: An Online Journal of Philosophy, 7:2 (2013), 95.

${ }^{54}$ Ibid.

${ }^{55} \mathrm{Ibid}$.

${ }^{56}$ Feorillo Demeterio, "Iris Marion Young's Theory of Structural Justice and Collective Responsibility," in Scientia: The Research Journal of the College of Arts and Sciences, 3:1 (2014), 142.

(c) 2018 Mary Irene Clare O. Deleña and Raymond John D. Vergara https://www.kritike.org/journal/issue 22/delena\&vergara june2018.pdf ISSN 1908-7330
}

(c) $)$ BY-NC-ND 
Leon, who, at the time of writing this piece, was his dissertation advisee at the University of Santo Tomas. The essay was published in Kritike: An Online Journal of Philosophy. This essay, written as well in Filipino, is Demeterio and De Leon's effort in similarly introducing Baudrillard's postmodern thoughts to Filipino readers from the fields of both philosophy and cultural studies. ${ }^{57}$ Their discussion on Baudrillard's philosophy is contained in three sections: 1) his Marxist phase, 2) his anti-Marxist phase, and 3) his postmodern phase. ${ }^{58}$ Demeterio and De Leon concluded the essay by again laying down five points on how Baudrillard's philosophy can be appropriated by Filipino philosophy and Philippine studies. ${ }^{59}$ This essay appears to be both an introduction of Baudrillard's philosophy to Filipino readers and a more concrete exploration on the possibility of appropriating Baudrillard's critical thought for the enrichment and development of Filipino philosophy and Philippine studies.

Demeterio wrote that postmodernism is a self-conscious cultural movement that ran counter against the principles of and tenets of modernism in culture, art and philosophy. The aspect of postmodernism that he analyzed revolved around the foundational, as he explored the Filipino attitudes towards science and technology, towards the nation-state, and towards progress, and examined the general Philippine organizational management, economic mode of production, and the state of industry; the cultural, as he analyzed the Filipino self, the Filipino attitude towards pleasure and consumption, and the Filipino art in general; and the theoretical, as he advocated for the appropriation of postmodern philosophical theories for the enrichment of Filipino philosophy. His discursive positioning is predominantly local/Philippine, although at some points this would become cosmopolitan. This means that his geographic positioning most of the time is that of a Filipino scholar. His underpinning concerns throughout these five essays are to: 1 ) appropriate postmodern theories to critique the Philippine aspiration for modernity; 2) propagate the use of postmodern theories to critique Philippine realities; and 3) insist on the possibility of ethics. His first underpinning concern is premised on his idea that the Philippines is still a premodern state and that its intellectuals are pushing it to become a modern state in a time when postmodern philosophy has already exposed the ailments of modernity. His second underpinning concern is premised on his belief, as a specialist on cultural studies, that postmodern philosophy can be advantageously appropriated and used to study the various aspects of Philippine reality. His third underpinning concern is clearly premised on his

\footnotetext{
${ }^{57}$ Feorillo Demeterio and Emmanuel De Leon, “Ang Pilosopiya ni Jean Baudrillard bilang Batayang Teoretikal sa Araling Pilipino," in Kritike: An Online Journal of Philosophy, 9:1 (2015), 108.

${ }^{58} \mathrm{Ibid}$.

${ }^{59} \mathrm{Ibid}$.
}

(c) 2018 Mary Irene Clare O. Deleña and Raymond John D. Vergara https://www.kritike.org/journal/issue 22/delena\&vergara june2018.pdf ISSN 1908-7330 


\section{POSTMODERNISM}

study and appropriation of Young's postmodern ethical theories. Demeterio's general appraisal of postmodernism is that it is something good. This means that for him, philosophy, ethics, cultural studies, and Filipino philosophy should welcome the influx of postmodern philosophical theories as these can be advantageously appropriated by Filipino scholars.

\section{Raymundo Pavo on Postmodernism}

Pavo is an assistant professor of philosophy at the University of the Philippines Mindanao. He is currently the chair of the Department of Social Sciences in the said university. He specialized on Filipino philosophy and on the intersection between philosophy and social sciences. Among the four philosophy scholars studied by this paper, Pavo is the only one who is not a professor and he does not even hold a doctor's degree yet, but in 2011, he published the essay "Filipino Philosophy and Post-Modernity" that this paper simply could not ignore.

Raymundo Pavo's "Filipino Philosophy and Post-Modernity" is published in the International Journal of Arts and Sciences. In this essay, Pavo underscored the significance of the post-modern tools in pushing for the progress of Filipino Philosophy. Postmodernism, according to Pavo, is "the privileging of the language of particulars" as seen mostly "in the growing appeal of situational perspectives and transitory vantage points" furthermore "since flux and cracks have occupied the forefront of discussions, thinking in the postmodern milieu can be analogous to make-shifts - temporary shelters to live by, nurture and defend." 60 For Pavo, postmodernism's inclination to particularities, differences and equivocity opened spaces for particular philosophies like Filipino philosophy. ${ }^{61}$ Pavo however does not belittle the significance of the universals. In his critique of Rolando Gripaldo's methodologies of doing philosophy, Pavo has vividly presented the significance of particulars in establishing the universals. ${ }^{62}$ In the citizenship notion of doing philosophy, the nationality of the individual doing the philosophy is considered. In the traditional notion of doing philosophy, the capacity of a person to do his/her own philosophy outside the paradigm of a philosophical system is considered. The person does not limit himself/herself to an absolute philosophical system. Rather, he/she is able to establish his/her own ideas that can contribute to enrichment of Filipino philosophy. In the social science and culture notion of doing philosophy, Pavo showed how Filipino thinkers have utilized culture, ethnicity, literature, language, all

\footnotetext{
${ }^{60}$ Raymundo Pavo, "Filipino Philosophy and Post-Modernity," in International Journal of Arts and Sciences, 3:15 (2010), 239.

${ }^{61}$ Ibid., 239.

62 Ibid., 250-251.
}

(c) 2018 Mary Irene Clare O. Deleña and Raymond John D. Vergara https://www.kritike.org/journal/issue 22/delena\&vergara june2018.pdf ISSN 1908-7330

(c) BY-NC-ND 
mini-narratives, in developing Filipino philosophy. ${ }^{63}$ Pavo, therefore argued for the enmeshing of social sciences and philosophy. Philosophy cannot simply disregard the particular life-world experiences of the people but on the other hand, philosophy cannot be simply reduced to the particular perspectives of people. The essay is an invitation to Filipino philosophy scholars to take advantage of the postmodern tolerance for ambiguity and hybridity and push for the development of Filipino philosophy.

Pavo expressed that postmodernism privileges the language of particulars, and that such is obvious in the trendiness of situational thinking and transitory point of views. The aspect of postmodernism that he analyzed revolved around the theoretical, as he dwelt only on the realm of philosophy. His discursive positioning is predominantly local/Philippine, although at some points this would become cosmopolitan. This means that his geographic positioning most of the time is that of a Filipino scholar. His underpinning concern throughout this essay is to take advantage of the postmodern tolerance for ambiguity and hybridity and push for the development of Filipino philosophy. Pavo's general appraisal of postmodernism is that it is something good. This means that for him, Filipino philosophy should not be terrified with the presence of postmodernism in the intellectual and philosophical landscape of our country.

\section{Comparative and Contrastive Readings}

Abulad and Co tackled postmodernism from the perspective of their mastery of continental and oriental philosophies; Demeterio, from his commitment to the use of critical philosophy as well as from his engagement with cultural studies; while Pavo, from his adherence to logical analysis and to the agenda of blending philosophy and social sciences. The following table compares and contrasts the thoughts of these four Filipino philosophy scholars:

${ }^{63}$ Ibid., 242.

(C) 2018 Mary Irene Clare O. Deleña and Raymond John D. Vergara https://www.kritike.org/journal/issue 22/delena\&vergara june2018.pdf 


\section{POSTMODERNISM}

\begin{tabular}{|c|c|c|c|c|}
\hline Themes & Romualdo Abulad & Alfredo Co & Feorillo Demeterio & Raymundo Pavo \\
\hline $\begin{array}{l}\text { Definition of } \\
\text { Postmodernism }\end{array}$ & $\begin{array}{l}\text { Postmodernism has a } \\
\text { negative component, } \\
\text { "the destructive act } \\
\text { that makes } \\
\text { everything } \\
\text { presumptuous, } \\
\text { which pulverizes any } \\
\text { entity that tends to } \\
\text { settle the mind, so } \\
\text { that even the mind } \\
\text { itself, the ego or } \\
\text { consciousness, needs } \\
\text { to be presupposed;" } \\
\text { but also has a } \\
\text { positive component, } \\
\text { "having so cleansed } \\
\text { our mental slate, we } \\
\text { are then open and } \\
\text { free enough to do the } \\
\text { more constructive } \\
\text { work." }\end{array}$ & $\begin{array}{l}\text { "Postmodernism is } \\
\text { an offshoot of the } \\
\text { meeting of Western } \\
\text { and Eastern thought. } \\
\text { It is also a way } \\
\text { looking at the event } \\
\text { from a 'land' } \\
\text { perspective or a 'fish- } \\
\text { eye' view. } \\
\text { Globalization, on the } \\
\text { other hand, may } \\
\text { require looking at the } \\
\text { same world from an } \\
\text { added 'birds-eye' } \\
\text { view." }\end{array}$ & $\begin{array}{l}\text { "Postmodernism ... } \\
\text { refers to a self- } \\
\text { conscious cultural } \\
\text { movement that } \\
\text { reacted against the } \\
\text { principles and ideals } \\
\text { of the modernist } \\
\text { movements in } \\
\text { literature, art, } \\
\text { architecture, film, } \\
\text { philosophy, etc." }\end{array}$ & $\begin{array}{l}\text { Postmodernism } \\
\text { refers to "the } \\
\text { privileging of the } \\
\text { language of } \\
\text { particulars. This is } \\
\text { most seen in the } \\
\text { growing appeal of } \\
\text { situational } \\
\text { perspectives and } \\
\text { transitory vantage } \\
\text { points. Since flux and } \\
\text { cracks have occupied } \\
\text { the forefront of } \\
\text { discussions, thinking } \\
\text { in the postmodern } \\
\text { milieu can be } \\
\text { analogous to make- } \\
\text { shifts - temporary } \\
\text { shelters to live by, } \\
\text { nurture and defend." }\end{array}$ \\
\hline $\begin{array}{l}\text { Aspects of } \\
\text { Postmodernism } \\
\text { Analyzed }\end{array}$ & $\begin{array}{l}\text { Theoretical and } \\
\text { Cultural }\end{array}$ & $\begin{array}{l}\text { Theoretical, Cultural } \\
\text { and Foundational }\end{array}$ & $\begin{array}{l}\text { Foundational, } \\
\text { Cultural, and } \\
\text { Theoretical }\end{array}$ & Theoretical \\
\hline $\begin{array}{l}\text { Discursive } \\
\text { Positioning }\end{array}$ & $\begin{array}{l}\text { Cosmopolitan and } \\
\text { Local/ Philippine }\end{array}$ & $\begin{array}{l}\text { Cosmopolitan and } \\
\text { Local/ Philippine }\end{array}$ & $\begin{array}{l}\text { Local/ Philippine and } \\
\text { Cosmopolitan }\end{array}$ & $\begin{array}{l}\text { Local/ Philippine and } \\
\text { Cosmopolitan }\end{array}$ \\
\hline $\begin{array}{l}\text { Underpinning } \\
\text { Concerns }\end{array}$ & $\begin{array}{l}\text { Insist on the } \\
\text { possibility of ethics; } \\
\text { insist on the } \\
\text { possibility of religion } \\
\text { and theology; make } \\
\text { sense of } \\
\text { postmodernism } \\
\text { using modern } \\
\text { continental } \\
\text { philosophies; take } \\
\text { advantage of the } \\
\text { postmodern method } \\
\text { of critique of } \\
\text { intellectual } \\
\text { foundations and } \\
\text { push for the } \\
\text { development of } \\
\text { Filipino philosophy }\end{array}$ & $\begin{array}{l}\text { Take advantage of } \\
\text { postmodernism as an } \\
\text { auspicious time for } \\
\text { the development of } \\
\text { Filipino philosophy; } \\
\text { Argue that } \\
\text { postmodernism } \\
\text { mooted the earlier } \\
\text { discourses of } \\
\text { nationalistic Filipino } \\
\text { philosophy; warn of } \\
\text { the impending } \\
\text { clashes and } \\
\text { destructions that } \\
\text { would precede the } \\
\text { real dialogues and } \\
\text { tolerance of } \\
\text { postmodernity; make } \\
\text { sense of } \\
\text { postmodernism } \\
\text { using eastern } \\
\text { philosophies; insist } \\
\text { on the possibility of } \\
\text { religion and theology }\end{array}$ & $\begin{array}{l}\text { Appropriate } \\
\text { postmodern theories } \\
\text { to critique the } \\
\text { Philippine aspiration } \\
\text { for modernity; } \\
\text { propagate the use of } \\
\text { postmodern theories } \\
\text { to critique Philippine } \\
\text { realities; insist on the } \\
\text { possibility of ethics }\end{array}$ & $\begin{array}{l}\text { Take advantage of } \\
\text { the postmodern } \\
\text { tolerance for } \\
\text { ambiguity and } \\
\text { hybridity and push } \\
\text { for the development } \\
\text { of Filipino } \\
\text { philosophy }\end{array}$ \\
\hline $\begin{array}{l}\text { General } \\
\text { Appraisal of } \\
\text { Postmodernism }\end{array}$ & Positive & $\begin{array}{l}\text { Positive and } \\
\text { Negative }\end{array}$ & Positive & Positive \\
\hline
\end{tabular}

Table 1: Summary of the Similarities and Differences of Abulad, Co, Demeterio, and Pavo's Thoughts on Postmodernism 
The definitions of postmodernism offered by these four Filipino philosophy scholars converged on the theoretical aspect of postmodernism, or postmodernism as a collection of philosophies and philosophical principles. Abulad and Pavo are similar in the sense that their definitions of postmodernism focused only on postmodernism's theoretical aspect. Co and Demeterio are similar in the sense that their definitions of postmodernism focused both on postmodernism's cultural and theoretical aspects. Only Co's definition of postmodernism encompassed the foundational, cultural and theoretical aspects of postmodernism.

Beyond their definitions, the four Filipino philosophy scholars again converged in the theoretical aspect of postmodernism. Pavo focused on the theoretical alone; Abulad focused on the cultural and theoretical aspects of postmodernism; while Co and Demeterio focused on the foundational, cultural and theoretical aspects of postmodernism. Pavo, therefore has the narrowest treatment of postmodernism; while Co and Demeterio have the widest treatment.

Concerning their discursive positioning, Abulad and Co and are similar in the sense that they tackled postmodernism more from a cosmopolitan point of view. This means that their geographic positioning most of the time is that of a global or international philosopher, and not much of a Filipino philosophy scholar. They only take the local/Philippine point of view as an afterthought, or whenever they remember to comment on the significance of their thoughts to the local/Philippine context. Demeterio and Pavo, on the other hand, are similar in the sense that they tackled postmodernism primarily from a local/Philippine point of view. This means that their geographic positioning most of the time is that of a Filipino philosophy scholar, and not much of a global or international philosopher. They are conscious of their being Filipino philosophers and writers who are trying to grapple with the significance of postmodernism to Filipinos and Filipino philosophy.

The following table compares and contrasts the underpinning concerns of the four Filipino philosophy scholars as they grappled with postmodernism:

\begin{tabular}{|l|c|c|c|c|}
\hline \multicolumn{1}{|c|}{ Underpinning Concerns } & $\begin{array}{c}\text { Romualdo } \\
\text { Abulad }\end{array}$ & Alfredo Co & $\begin{array}{c}\text { Feorillo } \\
\text { Demeterio }\end{array}$ & $\begin{array}{c}\text { Raymundo } \\
\text { Pavo }\end{array}$ \\
\hline Insist on the Possibility of Ethics & $\checkmark$ & & $\checkmark$ & \\
\hline Insist on the Possibility of Religion and Theology & $\checkmark$ & $\checkmark$ & & \\
\hline $\begin{array}{l}\text { Make Sense of Postmodernism Using Modern } \\
\text { Continental and Oriental Philosophies }\end{array}$ & $\checkmark$ & $\checkmark$ & & \\
\hline
\end{tabular}

(c) 2018 Mary Irene Clare O. Deleña and Raymond John D. Vergara https://www.kritike.org/journal/issue 22/delena\&vergara june2018.pdf 


\begin{tabular}{|c|c|c|c|c|}
\hline $\begin{array}{l}\text { Take Advantage of the Postmodern Preference } \\
\text { for Deconstruction, Ambiguity and Individuality } \\
\text { for the Development of Filipino Philosophy }\end{array}$ & $\checkmark$ & $\checkmark$ & & $\checkmark$ \\
\hline $\begin{array}{l}\text { Argue that Postmodernism } \\
\text { Mooted the Earlier Discourses of Nationalistic } \\
\text { Filipino Philosophy }\end{array}$ & & $\checkmark$ & & \\
\hline $\begin{array}{l}\text { Warn of the Impending Clashes and Destructions } \\
\text { that would Precede the Real Dialogues and } \\
\text { Tolerance } \\
\text { of Postmodernism }\end{array}$ & & $\checkmark$ & & \\
\hline $\begin{array}{l}\text { Appropriate Postmodern } \\
\text { Theories to Critique the Philippine Aspiration for } \\
\text { Modernity }\end{array}$ & & & $\checkmark$ & \\
\hline $\begin{array}{l}\text { Appropriate Postmodern Theories } \\
\text { to Critique Philippine Realities }\end{array}$ & & & $\checkmark$ & \\
\hline
\end{tabular}

Table 2: Summary of the Convergences and Divergences of the Underpinning Concerns of Abulad, Co, Demeterio and Pavo in Grappling with Postmodernism

The most recurrent underpinning concern from these four Filipino philosophy scholars is to take advantage of the postmodern preference for deconstruction, ambiguity and individuality for the development of Filipino philosophy. This underpinning concern is followed by: to insist on the possibility of ethics; to insist on the possibility of religion and theology; and to make sense of postmodernism using modern continental philosophies and oriental philosophies. Co has two uncommon concerns: to argue that postmodernism has mooted the earlier discourses of nationalistic Filipino philosophy; and to warn of the impending clashes and destructions that would precede the real dialogues and tolerance of postmodernism. Demeterio also has two uncommon concerns: to appropriate postmodern theories in critiquing the Philippine aspiration for modernity; and to appropriate postmodern theories in critiquing other Philippine realities.

Concerning their overall appraisal of postmodernism, all of the four Filipino philosophy scholars see the phenomenon positively, as an opportunity for Filipino philosophy to develop into a strong and meaningful discourse. The Filipino thinkers and writers can definitely take advantage of postmodernism. Only Co expressed that postmodernism has an almost Armageddonian negative dimension that we also should be prepared for before we can reap the benefits of its sincere dialogues and tolerant attitude.

At the bottom line, it is noticeable that these four Filipino philosophy scholars are not really postmodern philosophers, but intellectuals who are still committed to some modern and even premodern philosophical projects, such as the building of a stronger Filipino philosophy, the affirmation of ethics, and the affirmation of religion and theology. They presuppose that once the philosophical playing field has been leveled by postmodernism, and

(c) 2018 Mary Irene Clare O. Deleña and Raymond John D. Vergara https://www.kritike.org/journal/issue 22/delena\&vergara june2018.pdf ISSN 1908-7330 
that once Filipino philosophy, ethics, religion and theology have built new and stronger intellectual structures, such structures would be immune from persistent leveling of postmodernism. These Filipino philosophy scholars are not ready to embrace the momentariness and flimsiness of all intellectual structures built on postmodern grounds. If Demeterio wrote in his essay "Our Premodernity and their Tokens of Postmodernity: Reflections on the Philippine Condition" that postmodernism may be present in the Philippines at the theoretical level alone, this paper would like to modify his assertion that such presence could not be able to root deeply considering that the four Filipino philosophy scholars who grappled with postmodernism and who were analyzed in this paper were revealed in the end as thinkers who are not actually committed to postmodernism.

\section{Conclusion}

After thematically reading the selected texts of the four Filipino scholars of philosophy who grappled with postmodernism, and after subjecting their thematized thoughts to comparative and contrastive readings, this paper was able to show a number of things. First, their diverse definitions of postmodernism that emphasize the various aspects of this philosophical and cultural movement: Abulad, the critical edge of postmodern philosophy; $\mathrm{Co}$, the openness of postmodernism towards dialogues; Demeterio, postmodernism's reaction to and critique of modernism; and Pavo, the tolerance of postmodernism towards the language of particulars. Talking only of their definitions, Abulad and Demeterio's definitions can be clustered together for their emphasis on critique; while Co and Pavo's definitions can be clustered together for their emphasis on openness and tolerance. Second, these four Filipino philosophy scholars focused more on the theoretical aspect of postmodernism, then on the cultural, and least on the foundational aspect of postmodernism. Third, these four Filipino philosophy scholars took both cosmopolitan and local/Philippine discursive positioning; but Abulad and Co preferred the cosmopolitan discursive positioning, while Demeterio and Pavo preferred the local/Philippine discursive positioning. Fourth, the most recurrent underpinning concerns of these four Filipino philosophy scholars is to take advantage of the postmodern preference for deconstruction, ambiguity and individuality for the development of Filipino philosophy. While their least recurrent underpinning concerns are: to argue that postmodernism mooted the earlier discourses of nationalistic Filipino philosophy; to warn of the impending clashes and destructions that would precede the real dialogues and tolerance of postmodernism; appropriate postmodern theories to critique the Philippine aspiration for modernity; and to appropriate postmodern

(c) 2018 Mary Irene Clare O. Deleña and Raymond John D. Vergara

https://www.kritike.org/journal/issue 22/delena\&vergara june2018.pdf

ISSN 1908-7330

(cc) BY-NC-ND 
theories to critique Philippine realities. Fifth, the four Filipino philosophy scholars generally appraised postmodernism positively.

Department of Philosophy, De La Salle University, Philippines

\section{References}

Abellanosa, Rhoderick John, "Rorty's Philosophy of Education: Between Orthodoxy and Vulgar Relativism," in Kritike: An Online Journal of Philosophy, 4:2 (2010).

Abulad, Romualdo and Alfredo P. Co, Two Filipino Thomasian Philosophers on Postmodernism, ed. by Romualdo E. Abulad (Manila: UST Publishing House, 2004).

Clarin, Erwhin and Jennie Vergara Jocson, "Fragmentation, Intertextuality, and Hyperreality: The Postmodern and Popular Filipino Films," in Journal of Arts and Humanities, 5:5 (2016).

Contreras, Antonio, "Investigating Postmodern Politics in the Philippines Using Reflexivity Theory," in Philippine Political Science Journal, 32:55 (2011).

"Polity Beyond the State: 'Postmodernizing' Political Science in the Philippines," in Philippine Political Science Journal, 23:46 (2002).

De Schrijver, Georges, "Postmodernity and Theology," in Philippiniana Sacra, 27:81 (1992).

Demandante, Darlene, "Lacanian Perspectives on Love," in Kritike: An Online Journal of Philosophy, 8:1 (2014).

Demeterio, Feorillo, "Iris Marion Young's Theory of Structural Justice and Collective Responsibility," in Scientia: The Research Journal of the College of Arts and Sciences, 3:1 (2014).

"Our Premodernity and their Tokens of Postmodernity," in Philosophia: International Journal of Philosophy, 33 (2004).

"Understanding the Postmodern Culture and Philosophy," in Academia, <https://www.academia.edu/8244247/Understanding the Postmodern Culture and Philosophy>.

Demeterio, Feorillo and Emmanuel de Leon, "Ang Pilosopiya ni JeanFrancois Lyotard bilang Batayang Teoretikal sa Araling Pilipino," in Kritike: An Online Journal of Philosophy, 7:2 (2013).

Llanera, Tracy Ann, "Shattering Tradition: Rorty on Edification and Hermeneutics," in Kritike: An Online Journal of Philosophy, 5:1 (2011).

Mendoza, Daryl, "Commodity, Sign, and Spectacle: Retracing Baudrillard's Hyperreality," in Kritike: An online Journal of Philosophy, 4:2.

(c) 2018 Mary Irene Clare O. Deleña and Raymond John D. Vergara https://www.kritike.org/journal/issue 22/delena\&vergara june2018.pdf ISSN 1908-7330

(cc) BY-NC-ND 
Pada, Roland Theuas, "Eliciting a Sense of Normativity in Derrida through Honneth's Theory of Recognition," in Kritike: An Online Journal of Philosophy, 9:1 (2015).

Pavo, Raymundo, "Filipino Philosophy and Postmodernity," in International Journal of Arts and Sciences, 3:15 (2010).

Reyes, Raniel, "Deleuze's Bergsonism: Multiplicty, Intuition, and the Virtual," in Kritike: An Online Journal of Philosophy, 10:2 (2016).

Reyes, Raniel, "Deleuze contra Hegel: The Rupture of the Dialectics towards Non-Conceptual Differences," in Kritike: An Online Journal of Philosophy, 8:2 (2014).

Yapo, Jerry, "Pastiche as the Aesthetic of Postmodernism in Jessica Hagedorn's Dogeaters," in The UPLB Journal, 6:1 (2009).

(C) 2018 Mary Irene Clare O. Deleña and Raymond John D. Vergara https://www.kritike.org/journal/issue 22/delena\&vergara june2018.pdf 